\title{
CHOLECYSTECTOMY: INDICATIONS AT UNIVERSITY OF Calabar Teaching Hospital, Calabar, Nigeria
}

\author{
M. E. Asuquo, M. S. Umoh, V. Nwagbara, A. Inyang and C. Agbor \\ Department of Surgery, University of Calabar Teaching Hospital, Calabar, Nigeria \\ Reprint requests to: Dr. Maurice Efana Asuquo, P. O. Box 1891(GPO), Calabar, Nigeria. \\ E-mail: mauefas@yahoo.com
}

\begin{abstract}
Background/objective: The relative rarity of gallbladder disease has been documented in various parts of Africa. Recently the incidence has been reported as rising in some African countries. We undertook this study to evaluate the indications for cholecystectomy in our center and compare with others.

Methods: This is a retrospective study of 18 open cholecystectomies in 10years.

Results: The ages ranged from 13 and 65 years (mean 39.2years). There were 15 females and 3 males (F: $\mathrm{M}=$ ratio $5: 1$ ). Calculous cholecystitis $9(50 \%)$ in patients, acalculous cholecystitis $8(44.4 \%)$ and a patient with carcinoma of the gallbladder were offered cholecystectomy. The commonest stone was mixed multiple stones.

Conclusion: The numbers of cholecystectomies attest to the rarity of gallbladder disease in this environment. This may be due to the high fiber and low cholesterol diet predominant in this costal population in southern Nigeria.
\end{abstract}

Key words: Cholecystectomy, cholecystitis, gallstones

\begin{abstract}
Résumé
Introduction/Objectif: La rareté relative de la maladie de la vésicule biliaire a été documenté dans la plupart des pays africains. Jusqu'à récemment la fréquence a été rapportée comme en hausse dans quelques pays africains. Nous avons entrepris cette étude afin d'évaluer les indications de la cholécystectomie dans notre centre et les comparé avec d'autres.

Méthodes: Il s'agit d'une étude rétrospective de 18 cholécystectomies ouvertes au cours d'une durée de dix ans.

Résultats: Les âges varient entre 13 et 65 ans (moyenne 37,2 ans.) Il y a eu 15 du sexe féminin et 3 du sexe masculin (F: $M=$ proportion de 5:1). Cholécystites calculs de 9 soit $50 \%$ chez les patients cholécystite acalculies de 8 soit $44,4 \%$ et un patient atteint d'un cancer de la vésicule biliaire a été donné la cholécystectomie. Un mixte de multiples pierres était la pierre la plus fréquente.

Conclusion: Le nombre des cholécystectomies confirme la rareté de la maladie vésiculaire dans cet environnement. Cela peut être du à la haute teneur en fibres et faible taux de cholestérol alimentaire prédominant dans cette population costale dans le sud du Nigéria.
\end{abstract}

Mots clés:- Cholécystectomie, cholécystite biliaire

\section{Introduction}

The relative rarity of gallbladder disease has been reported in parts of Africa. ${ }^{1,2}$ In recent times the incidence has been rising. ${ }^{3,4}$ Reports from parts of this country indicate the rarity of this disease. ${ }^{5,6}$ However, cholelithiasis and cholecystitis are common in developed countries, thus making cholecystectomy one of the most common operation. ${ }^{7}$ We undertook this study to evaluate the indications for cholecystectomy in our setting. 


\section{Materials and Methods}

Patients who had cholecystectomy in the University of Calabar Teaching Hospital, Calabar between July1994 and June-2004 were evaluated from records retrieved from medical records and operating theater. The indices analyzed were biographic data, clinical features, radiologic, operative, histologic findings and outcome of treatment.

\section{Results}

A total of 18 open cholecystectomies were done for gallbladder diseases in the period under review (July
1994 - June 2004). There were 15 females and 3 males ( $M: F=5: 1$ ) (Table1). The ages ranged from 13 to 65 years with a mean of 39.2 years. Five were students, 9 civil servants, 3 farmers and a trader.

The symptoms and signs are as shown on Table 2. Right upper quadrant pain was the most consistent symptom in $17(94.4 \%)$ patients. Murphy's sign was positive in $10(55.6 \%)$ patients and no patient presented with jaundice.

Nine $(50 \%)$ of the patients had ultrasonography in the later $5 y e a r s$ period of study when it became available and in $4(88.9 \%)$ patients the findings were consistent with operative and histologic results with one false-positive result.

Table 1. Age and sex of 18 patients undergoing cholecystectomy

\begin{tabular}{llll}
\hline Age (years) & Sex & Total \\
$0-10$ & M & F & - \\
$11-20$ & 1 & - & 2 \\
$21-30$ & 1 & 1 & 4 \\
$31-40$ & - & 3 & 4 \\
$41-50$ & 1 & 4 & 4 \\
$51-60$ & - & 3 & 3 \\
$61-70$ & - & 3 & 1 \\
Total & 3 & 1 & 18 \\
\hline
\end{tabular}

Age range: $13-65$ y; Mean: 39.2years

Table 2. Clinical features in 18 patients undergoing cholecystectomy

\begin{tabular}{ll}
\hline Clinical feature & No. \\
Right upper quadrant pain & 17 \\
Epigastric pain & 1 \\
Epigastric pain & 1 \\
Nausea and vomiting & 1 \\
Family history & - \\
Jaundice & 18 \\
Tenderness (Murphy's' sign) & 10 \\
Hepatomegally & - \\
\hline
\end{tabular}

Table 3. Operative findings in 18 patients undergoing cholecystectomy

\begin{tabular}{|c|c|}
\hline Finding & No. \\
\hline \multicolumn{2}{|l|}{ Calculous cholecystitis } \\
\hline Solitary* & 2 \\
\hline Multiple stones & 7 \\
\hline \multicolumn{2}{|l|}{ Acalculous cholecystitis } \\
\hline Chronic cholecystitis & 8 \\
\hline Carcinoma of the gallbladder & 1 \\
\hline Total & 18 \\
\hline
\end{tabular}

Table 3 shows the operative findings which were confirmed by histology. Nine (50\%) patients had calculous cholecystitis, $8(44.4 \%)$ with acalculous cholecystitis and a patient with carcinoma of the gallbladder. Anatomical abnormalities were found in the two patients with solitary stones: one with a partially buried gallbladder in the liver except the Hartman's pouch where the solitary stone was lodged, and the other with an incomplete septum in the body of the gall bladder. A patient out of the seven with multiple stones was a sickler with extensive bilateral chronic leg ulcers. There was no patient with clinical evidence of jaundice and at surgery there was no patient with a dilated or stone palpable in the common bile duct.

One patient had surgical site infection. The patient with the partially buried gallbladder developed a biliary fistula that resolved from bile leakage arising from the gallbladder bed confirmed at re-exploration. There was no mortality.

\section{Discussion}

A total of 18 patients had open cholecystectomy for gallbladder diseases in $10 y e a r s$ resulting in a hospital prevalence of less than 2 per year. 
The true incidence of gallbladder diseases in most parts of Africa is largely unknown; our finding indicates the rarity of this disease in this environment. This compares with other results in this country $^{5,6}$ and other African countries ${ }^{2,8}$ but at variance with others that showed an increasing trend $^{3,4,9}$ which may have been due to the use of USS. However in our study, the use of USS in the later $5 y e a r s$ of this study did not show any increase in the number of cholecystectomy performed.

The female to male ratio was $5: 1$; this is in keeping with another study, ${ }^{8}$ but at variance with other reports locally and world wide with a ratio of $2: 1$. $^{5,10,11}$ The peak age in this study spread between 21-50years with a mean of 39.2 years. This is in keeping with another study in Northern Nigeria ${ }^{5}$ but at variance with Lagos-(60-69years), ${ }^{6}$ Ibadan, Enugu, ${ }^{12}$ Uganda $^{8}$ (40-59years).

Diagnosis was clinical, radiologic and confirmed by histology. Right upper quadrant pain was present in $17(94.4 \%)$ and Murphy's sign positive in 10 (55.6\%). Notably there was no patient with a history of jaundice recorded in this study,(Table2) and in addition there was no dilated nor stones palpable in the common bile duct during surgery. Obstructive jaundice in this environment is invariably due to pancreatic lesions. Ultrasonography was consistent with operative and histologic findings in $4(88.9 \%)$ patients with a false positive report in one.

Calculous cholecystitis was found in 9 (50\%) of the patients, (Table3). The prevalence of cholelithiasis is substantially lower in African patients than in North American patients, this may partly be due to lower dietary cholesterol and a high fiber in our diet. Anatomical variation/abnormality may encourage stasis and contribute to cholelithiasis as we found a solitary stone in a patient with an incomplete septum in the body of the gallbladder. Another solitary stone was found in a patient aged $13 y e a r s$ with a partially buried gallbladder in the liver sparing the Hartman's pouch where the large solitary stone was lodged. There was a sickler with chronic bilateral leg ulcers with symptomatic cholelithiasis. Sickle cell disease is recognized as predisposing to cholelithiasis; however the sickle cell trait does not carry a particular liability to gall stone formation.

Chronic acalculous cholecystitis was $8(44.4 \%)$ in this study, other studies reported $35 \%-37 \%$ in Nigerians with gallbladder disease. ${ }^{5,13}$ This may be attributable to a functional deficiency in gallbladder emptying mechanism. ${ }^{14,15}$ In a patient with a preoperative diagnosis of chronic acalculous cholecystitis, carcinoma of the gallbladder was diagnosed at laparotomy Nevin stage Vand confirmed on histology. Gallbladder cancer is commoner than generally recognized. No figures are available in developing countries but on impression the incidence is no less disquieting. Typically if patient is symptomatic at the time of tumor recognition, it is too far advanced for curative surgery as was the case in this study. She was lost to follow up.

Two (22.2\%) of the stones were solitary, $7(77.8 \%)$ multiple and they were all mixed stones. Other studies in this country portray similar findings. ${ }^{9}$ There was no hospital mortality; the average duration of admission was 9days. Hospitalization was prolonged by surgical site infection and biliary fistula which closed spontaneously.

\section{References}

1. Badoe EA, Archampong EQ, da Rocha Afodu JT. Principles and practice of surgery, including pathology in the tropics and subtropics. Ghana Publishing Cooperation, Tema, 2000; 704.

2. Gelfand $M$. The incidence of gallstones in Zimbabwe. Cent Afr J Med. 1981;27:46-47.

3. Darko $R$, Archampong EQ. Changing pattern of cholelithiasis in Accra. West Afr J Med. 1994;13:204-208.

4. Akute OO, Obajimi MO. Cholelithiasis in Ibadan: an update. West Afr J Med. 2002;21:128-131.

5. Dauda MM, Yusufu LMD, Attah MM. Cholecystitis and cholelithiasis in adults in Zaria. Trop Doct. 2005;35:243-245.

6. da Rocha Afodu JT, Adesola AO. Cholecystitis in Nigerians. Journal of Nigerian Medical Association. 1971;1:45-50.

7. Moreaux J. Prospective study of open cholecystectomy for calculous biliary disease. $\mathrm{Br}$ J Surg. 1994;8:116-119.

8. Sharper AC, Patel MK. Diseases of the biliary tract in Africans in Uganda. East Afr Med J. 1964;41:246-250.

9. Rhaman GA. Cholelithiasis and cholecystitis: changing prevalence in an African Community. J Natl Med Assoc. 2005;97:1534-1537.

10. Allen J, Cuschieri A. Cholelithiasis. eMedicine 2005; April 26: 1-12.

11. Gladden DO, Migala AF. Cholecystitis. eMedicine 2005; July 20: 1-22.

12. Ojukwu JO, Okafor JC. Incidence of cholecystitis and cholelithiasis seen in UNTH, Enugu, Nigeria. Part 1: Period 1976-1981. Journal of College of Medicine (Nigeria). 1999;4:84-86.

13. Amaral J, Xiao ZL, Chen Q. Gallbladder muscle dysfunction in patients with chronic acalculous disease. Gastroenterology. 2001;120:506-511.

14. Adams DB, Tarnasky PR, Hauves RH. Outcome after laparoscopic cholecystectomy for chronic acalculous cholecystitis. Am Surg. 1998;64:1-6.

15. Frezza EE, Mezghebe H. Gallbladder carcinoma. A 28 yr experience. Int Surg. 1997;82:295-300. 